\title{
Article
}

\section{The Benefits of Fit-for-Purpose Land Administration for Urban Community Resilience in a Time of Climate Change and COVID-19 Pandemic}

\author{
David Mitchell ${ }^{1, *(D)}$, Bernhard Barth ${ }^{2}$, Serene Ho ${ }^{1}$ (D) M. Siraj Sait ${ }^{3}$ and Darryn McEvoy ${ }^{4}$ (D) \\ 1 Geospatial Science, School of Science, RMIT University, Melbourne 3000, Australia; serene.ho2@rmit.edu.au \\ 2 UN-Habitat, Regional Office for Asia and the Pacific, Fukuoka 810-0001, Japan; bernhard.barth@un.org \\ 3 Noon Centre for Equality and Diversity, University of East London, London E16 2RD, UK; s.sait@uel.ac.uk \\ 4 School of Engineering, RMIT University, Melbourne 3000, Australia; darryn.mcevoy@rmit.edu.au \\ * Correspondence: david.mitchell@rmit.edu.au
}

\section{check for}

updates

Citation: Mitchell, D.; Barth, B.; Ho, S.; Sait, M.S.; McEvoy, D. The Benefits of Fit-for-Purpose Land Administration for Urban Community Resilience in a Time of Climate Change and COVID-19 Pandemic. Land 2021, 10, 563. https://doi.org/10.3390/ land10060563

Academic Editors: Stein T. Holden, Fabrizio Battisti and Stig Enemark

Received: 5 April 2021

Accepted: 18 May 2021

Published: 27 May 2021

Publisher's Note: MDPI stays neutral with regard to jurisdictional claims in published maps and institutional affiliations.

Copyright: (c) 2021 by the authors. Licensee MDPI, Basel, Switzerland. This article is an open access article distributed under the terms and conditions of the Creative Commons Attribution (CC BY) license (https:/ / creativecommons.org/licenses/by/ $4.0 /)$.

\begin{abstract}
The major global pressures of rapid urbanization and urban growth are being compounded by climate impacts, resulting in increased vulnerability for urban dwellers, with these vulnerabilities exacerbated during the COVID-19 pandemic. Much of this is concentrated in urban and periurban areas where urban development spreads into hazard-prone areas. Often, this development is dominated by poor-quality homes in informal settlements or slums with poor tenure security. Lessons from a resilience-building project in the Pacific shows that a fit-for-purpose (FFP) approach to land administration can provide solutions by increasing the number of households with security of tenure, and consequently, improving resilience outcomes as informal settlements grow. This paper specifically discusses the influence of FFP land administration on reducing vulnerabilities to external shocks, such as climate change and COVID-19. It proposes ways to be better manage urban growth through the responsible governance of land tenure rights and more effective land-use planning to improve resilience to multiple shocks and stresses, hence, delivering improved access to safe land and shelter. Land administration systems can contribute to enhanced resilience to the shocks of climate extremes and pandemics by improving tenure security and enhancing land-use planning controls. It is argued that climate change adaptation and disaster risk reduction need to be better mainstreamed into two major elements of land governance: (i) securing and safeguarding of land rights, and (ii) planning and control of land use.
\end{abstract}

Keywords: fit-for-purpose land administration; rapid urbanization; climate change; pandemic; urban resilience

\section{Introduction}

Urbanization is a key driver of both climate vulnerability and tenure insecurity in urban settlements in the Global South [1]. The global pressures of rapid urbanization and urban growth are being compounded by the impact of a changing climate, resulting in the increased vulnerability of urban dwellers. Land-use planning has not controlled the growth of informal settlements, which often occur in highly vulnerable areas [2], with inadequate housing, insecure tenure, and no formal access to water and sanitation, making them particularly sensitive to climate impacts [2].

The recent literature has described the interrelationships between land tenure and climate vulnerability as well as potential land governance responses [3]. Insecure land tenure exacerbates vulnerability to climate-related hazards [3,4], as these households are disconnected from formal governance processes, lack knowledge to inform resilience decisions, and have restricted access to finance for actions to strengthen their adaptive capacity [5]. Those without formal land records are also more likely to be excluded from post-disaster reconstruction programs and grants [6,7]. Climate impacts lead to human mobility (migration, displacement, and resettlement) with impacts to tenure security [3]. 
The importance of 'responsible' land governance to secure access to land for shelter and livelihoods and reduce disaster vulnerability is recognized in the Committee on World Food Security (CFS)-endorsed 'Voluntary Guidelines on the Responsible Governance of Tenure of Land, Fisheries and Forests in the Context of National Food Security' (VGGTs). The VGGTs call on states to ensure that legitimate tenure rights are respected and protected for effective land-use planning [8]. To improve both resilience and tenure security at scale, climate adaptation and disaster risk management need to be better mainstreamed into two major elements of responsible land governance: (i) securing and safeguarding of all formal and informal land tenure rights, and (ii) effective planning and control of land use to prevent housing in the most hazard-prone locations $[3,6]$. Taking a responsible land governance approach informed by the VGGTs provides a pathway to address tenure security in the process of strengthening urban resilience, especially for marginalized communities.

Urban housing needs to be more climate resilient to meet the Global 2030 Agenda; providing secure land tenure for all should be a fundamental aim. With the ongoing impact of the global COVID-19 pandemic, what is less well understood are the interlinkages between land tenure, climate vulnerability, and pandemics. As the 'UN Special Rapporteur on the right to adequate housing' noted, "By ensuring access to secure housing with adequate sanitation, States will not only protect the lives of those who are homeless or living in informal settlements but will help protect the entire world's population by flattening the curve of CV19" [9]. While the recent literature has focused on understanding the interrelationships between land tenure and pandemics $[10,11]$, there has been little to no research yet on the interlinkages between land tenure and multiple shocks, such as the impact of climate extremes and pandemics.

The emphasis on land tenure in the context of climate and pandemic shocks draws attention to the potential application of fit-for-purpose land administration (FFP LAS) in the context of both climate change and pandemics, where there is significant literature on how the FFP LAS approach can improve tenure security at scale [12,13] by (i) using methods that fit the context, (ii) being flexible in terms of accuracy requirements of land tenure information and adopting a continuum of land rights approach, and (iii) starting with low-cost approaches and allowing for incremental improvement. The approach involves developing the core FFP LAS components of the spatial, legal, and institutional frameworks. This paper focuses on the overall aim of tenure security at scale through responsible land governance, and on using high-resolution imagery rather than field surveys to develop the spatial framework component of FFP LAS [12].

A significant post-earthquake project in Nepal illustrated the benefits of applying the FFP LAS approach to document existing people-land relationships to support improved tenure security and disaster and climate resilience efforts [4,7]. The application of FFP LAS and other tools, such as participatory enumeration and the Social Tenure Domain Model (both discussed later), provided the tools to record and recognize all existing land tenure rights to inform both land administration and disaster reconstruction activities. However, to the authors' knowledge, there is no existing literature on the benefits of FFP LAS to support responses to both climate and pandemic impacts. This paper addresses this gap by using the context of an ongoing research project in Honiara, Solomon Islands, to consider how FFP LAS can support climate resilience building to address vulnerability to both climate and pandemic impacts.

The aim of this paper is to describe how improving tenure security at scale, using the FFP LAS approach, can enhance climate resilience to both climate and pandemic impacts. This contributes to the literature through introducing new principles and methods for applying FFP LAS to urban resilience initiatives.

Several of the authors have a long-standing engagement through a UN-Habitat-led climate adaptation planning process, culminating in the Honiara Urban Resilience and Climate Action Plan (HURCAP) [14]. The research methods include an extensive literature review of the interrelationships between land tenure, climate change and pandemics. The empirical data are drawn from two sources. Firstly, data are derived from participatory 
action research that commenced in 2012 under UN-Habitat 'Cities and Climate Change Initiative' and is continuing through the Climate Resilient Honiara (CRH) project support by the UNFCCC Adaptation Fund, which commenced in 2018 [15]. The lessons from this engagement in Honiara include experiences prior to and during the COVID-19 pandemic.

Secondly, data are also derived from a recent rapid assessment of COVID-19 carried out by UN-Habitat, which provides insights into the socioeconomic impacts on residents in five communities across Honiara [16]. This rapid assessment involved surveys with 100 households across four wards in Honiara during the period 17-31 August 2020. Respondents were randomly selected from informal settlements participating in the ongoing CRH project. The study examined six key areas: (1) livelihood security and household income, (ii) food security, (iii) access to health care, (iv) knowledge, attitudes and practices related to COVID-19, (v) climate related hazards and COVID-19, and (vi) tenure security [16].

\section{Pandemics and Land Tenure Rights}

Global changes in land-use patterns and an accelerating rate of land conversion are recognized as contributing factors in increased pandemic risk and the emergence of new infectious diseases, due to diminishing natural habitats and ecological disruption [17,18]. Health emergencies, such as the 2003 severe acute respiratory syndrome (SARS), 2009 H1N1 influenza (or "swine flu"), the 2014 West African Ebola crisis, and more recently, the 2016 Zika outbreak in the Americas [19], demonstrate not merely similarities between climate change and health risks, but their intertwined trajectories (see [20-22]). COVID-19 underscores the need to rethink land-use change and the preparedness of health systems by closing critical knowledge gaps and fostering society-wide engagement in pandemic risk reduction in the new 'pandemic era' [23]. A case study of slum dwellers in Liberia shows how multiple vulnerabilities arise out of their location-exposure to climate risks, the impacts of past epidemics, such as Ebola, and socioeconomic profiles given prolonged civil war and displacement [11]. Instead of a linear approach that creates a dichotomy between health responses and other vital societal adaptation, the common socioeconomic and ecological determinants that disproportionately affect certain categories by gender, age, ethnicity and landlessness, and other vulnerabilities need to be addressed concurrently.

Recent research attest to how unsustainable urbanization-with its knock-on effects on human health and wellbeing-is a critical part of reducing the risk of future pandemics [24-27]. Human development choices directly impact the natural world, and biodiversity and natural habitats are conditioned on sustainable urbanization and the responsible human consumption of animal products to prevent new, communicable zoonotic diseases. While pandemics are often viewed as health crises, the socioeconomic implications are under-researched, often overlooking urban resilience and sustainability. Enforced border shutdowns, travel restrictions and quarantines have highlighted the impact of the virus on the global economy, affecting well-being, employment opportunities, and food security [28]. Thus, responsible land administration approaches in the future will have to respond to concerns across various levels.

The nature of pandemic risks, in relation to land tenure rights, intersects the loss of livelihoods, threats of eviction, and changes to human mobility patterns. Pandemics exacerbate unaffordability of adequate housing and existing characteristics in many informal settlements-poor sanitation, high density housing, insecure tenure rights, and mobile populations-and therefore, contribute to the complexity in addressing health risks $[29,30]$. Loss of livelihoods, affecting the ability to pay rent and mortgages, eviction, and human mobility, while elements of the stressors of urbanization and climate-related impacts became more critical issues during the COVID-19 pandemic. Impacts on access to drinking water and sanitation for vulnerable households, as well as overcrowding in affected households, are also risk factors [31].

The restrictions imposed during the pandemic interrupted urban services, such as access to drinking water and sanitation, and the capacity of local actors to intervene to redress these risks due to social distancing, lockdowns, and diminishing resources [32,33]. 
An effective way of tackling complex land, housing, environmental and health challenges is to understand the linkages and pooling of resources through local perspectives and community-led action.

As with earlier epidemics, such as Ebola and HIV, COVID-19 exposed how the urban poor (including migrants and slum communities) struggle with household size, housing costs, livelihoods and tenure security, while encountering unfavorable structural, economic, and political conditions [19]. Strategies, such as hand washing, self-isolation, or selfquarantine after exposure to the virus, physical distancing, and 'work from home' advice are based on elitist assumptions. Those living in urban informal settlements need additional support, as well as local knowledge to create equitable systems for the most vulnerable populations [34]. The 'new normal' for future cities and communities requires a shift toward a 'new social contract' that fosters rights-based, well-planned, inclusive and climateresilient cities [31]. Building back better in the face of climate change and the COVID-19 pandemic will need be centered upon future innovative land-use decisions and sustainable urban development practices.

The drivers and pandemic vulnerabilities discussed above are summarized in Table 1 below.

Table 1. Major issues and drivers impacting pandemic vulnerability.

\begin{tabular}{cc}
\hline Issue/Driver & Pandemic Vulnerabilities \\
\hline $\begin{array}{c}\text { Urbanization leading to unplanned urban } \\
\text { growth in slums and informal settlements. } \\
\text { Increased density of development }\end{array}$ & $\begin{array}{c}\text { Increased vulnerability to disease. Limited } \\
\text { ventilation between buildings } \\
\text { exacerbates disease. }\end{array}$ \\
\hline $\begin{array}{c}\text { Slums and informal settlement with limited } \\
\text { access to formal water supply and sanitation }\end{array}$ & $\begin{array}{c}\text { Poor water supply and sanitation impacts } \\
\text { health and spread of disease. }\end{array}$ \\
\hline $\begin{array}{c}\text { Informal settlement occupants may not be } \\
\text { included in DRR, CCA, resilience or disaster } \\
\text { reconstruction programs }\end{array}$ & $\begin{array}{c}\text { May result in some households not receiving } \\
\text { government pandemic grants and support. }\end{array}$ \\
\hline $\begin{array}{c}\text { Poor quality house construction and materials } \\
\text { Human mobility as an adaptive response }\end{array}$ & $\begin{array}{c}\text { Densely populated settlements impact } \\
\text { pandemic responses and spread of disease. }\end{array}$ \\
\hline Pandemic restrictions limit adaptive human \\
mobility opportunities.
\end{tabular}

\section{Climate Change, COVID-19 and Land Administration in Pacific Islands Countries}

3.1. The Socio-Economic Impact of Urbanization, Climate Extremes and the COVID-19 Pandemic on Urban Systems in the Pacific Island Countries

Pacific Island Countries (PICs) are highly exposed to natural hazards, such as earthquakes, cyclones, and tsunamis. They are affected by the El Niño-Southern Oscillation (ENSO), which creates climate variability and impacts each PIC differently. These 'natural' regional climate cycles influence extreme events, such as drought, flooding, and tropical cyclones [35]. During April 2020, the PICs faced the widespread destruction caused by Tropic Cyclone Harold in the Solomon Islands, Vanuatu, Fiji, and Tonga, which compounded the impacts of COVID-19 and presented additional challenges through damages to crops, homes, buildings, and roads [16].

Rapid border closures and swiftly imposed lockdowns curtailed the impact of COVID19 in the region and at the end of 2020, only four of the 14 PICs had confirmed cases. Nonetheless, the experience of Papua New Guinea this year underscores the fragility of this stability and how quickly PICs can be overwhelmed due to existing and entrenched development challenges. Indeed, the use of widespread lockdowns and states of emergency, while undoubtedly saving lives, have resulted in extensive externalities in terms of 
macroeconomic pressures for governments as well as myriad socioeconomic impacts for PIC communities, particularly urban ones.

Most people in PICs live in cities and towns. Urban growth rates continue to exceed annual population growth rates in nearly all Pacific economies [16]. This growth is especially significant in Melanesia, where the urban growth rate of some countries, such as the Solomon Islands, exceeds $5 \%$ and its capital, Honiara, has a population density of nearly 6000 persons per square kilometer [36]. The total population of Pacific countries is forecast to grow by more than $60 \%$ by 2050 (to almost 20 million), propelled by growth in just four countries: Vanuatu, Kiribati, the Solomon Islands, and Papua New Guinea [37]. This presents challenges for every development sector.

Pacific urbanization is characterized by social, cultural, linguistic, political, economic, and environmental diversity across Melanesia, Micronesia, and Polynesia. Climate impacts, informal settlement, urban poverty, and infrastructure deficiencies undermine urban resilience. Within informal settlements, the challenges include evictions and discrimination, with the more vulnerable and marginalized being most affected. The degree of resilience of households is a major factor in how they transition from an informal settlement to a formally recorded settlement [35].

Currently, around one in four PIC residents live below national poverty lines; for seven out of 11 PICs, this is more likely to be the experience for urban populations rather than rural ones [38]. Livelihoods are heavily reliant on informal and subsistence economies: limited labor statistics for PICs show that informal employment rates can range between around $30 \%$ (e.g., Cook Islands) to $80 \%$ (e.g., Tonga). Hence, the informal economy is significant for PICs and although accounting of the impact is difficult, a case study in Fiji shows that the informal economy contributes around 15\% toward GDP $[39,40]$. During COVID-19, restricted movements and lockdowns meant that these economies ground to a halt and many were forced to turn to subsistence rather than cash economies. Although subsistence economies are already dominant in PICs such as Solomon Islands and Papua New Guinea, especially in rural areas (ILO Office for Pacific Island Countries), for urban communities, this undoubtedly placed more pressure on already scarce (and often contested) land resources. However, during COVID-19, many PIC governments mandated a return to rural islands under state-of-emergency powers, which reversed longstanding patterns of rural-urban and inter-island migration.

Demographic trends in the region mean that half of the population are below 24 years of age, especially in the Melanesian countries of Solomon Islands, Vanuatu, and Papua New Guinea. The youth bulge tends to be concentrated in urban areas, and youth in these areas are more likely to face increased poverty, chronic health issues, poor educational outcomes, unemployment, and higher risks of political and socioeconomic grievance [41]. Additionally, geography is a significant factor impacting development, especially in countries such as the Federated States of Micronesia, which comprises 607 islands spread across a large area, imposing unique challenges for coordination and distribution of services. A recent study demonstrates that $50 \%$ of Pacific people live within one $\mathrm{km}$ of the coast and $90 \%$ live within five $\mathrm{km}$ of the coast (excluding Papua New Guinea, as its exponentially greater population numbers skews the analysis) [42]. In recent years, a growing trend in rural-to-urban migration and inter-island migration has led to an increase in informal settlements as a dominant urban form throughout PICs [39]. These coastal urban areas are exposed to an array of climate-related impacts, including sea level rise, storm surges and cyclones.

These environmental risks are exacerbated by limited adaptive capacities. Some of these are consequences of physical isolation and the physical sizes of the countries themselves but PICs also experience chronic structural issues that produce weak governance systems, infrastructure deficits, and a lack of diversity in internal and external trade markets, all of which contribute to poor socioeconomic development outcomes for urban residents [43]. Consequently, the 2020 World Risk Index identifies three PICs as being in the 
top five most-at-risk countries in the world: Vanuatu (first), Tonga (second), and Solomon Islands (fifth).

The introduction of a pandemic into such contexts severely tests the limits and capacities of urban systems to cope. Furthermore, institutional ambiguity over the governance of urban informal settlements often creates conflict over who is responsible for land governance and basic service provision, resulting in many settlements living without access to basic sanitation and water facilities. Urban informal settlements are, therefore, particularly vulnerable to the health and socioeconomic impacts of COVID-19: crowded housing, the existing prevalence of vector-borne diseases, coupled with limited access to clean water and sanitation, and higher rates of chronic health conditions. All serve to create ideal conditions for a virus to spread.

\subsection{Land Tenure Issues and Vulnerability to Multiple Shocks and Stresses in Honiara \\ 3.2.1. Tenure Security Issues in Honiara}

Honiara, the capital city of the Solomon Islands, is situated on a narrow coastal strip, spreading out into a series of rugged hills and valleys to the south (see Figure 1). It faces a wide range of severe climate hazards exacerbated by shortcomings in urban development and infrastructure. Flood events, extreme heat, drought, sea level rise, and landslides are projected to increase in intensity and frequency due to a changing climate [44]. Informal settlements are often located in exposed coastal areas, river floodplains, or steep hilly terrain. As such, they are highly exposed to climate-related hazards, adding to the existing underlying vulnerabilities $[5,45]$. The high levels of exposure and sensitivity to extreme events and limited adaptive capacity mean that the current-day vulnerabilities of informal settlements are considered priorities over future events, with local actions needed to increase urban resilience to a combination of urbanization and climate-related drivers [5].

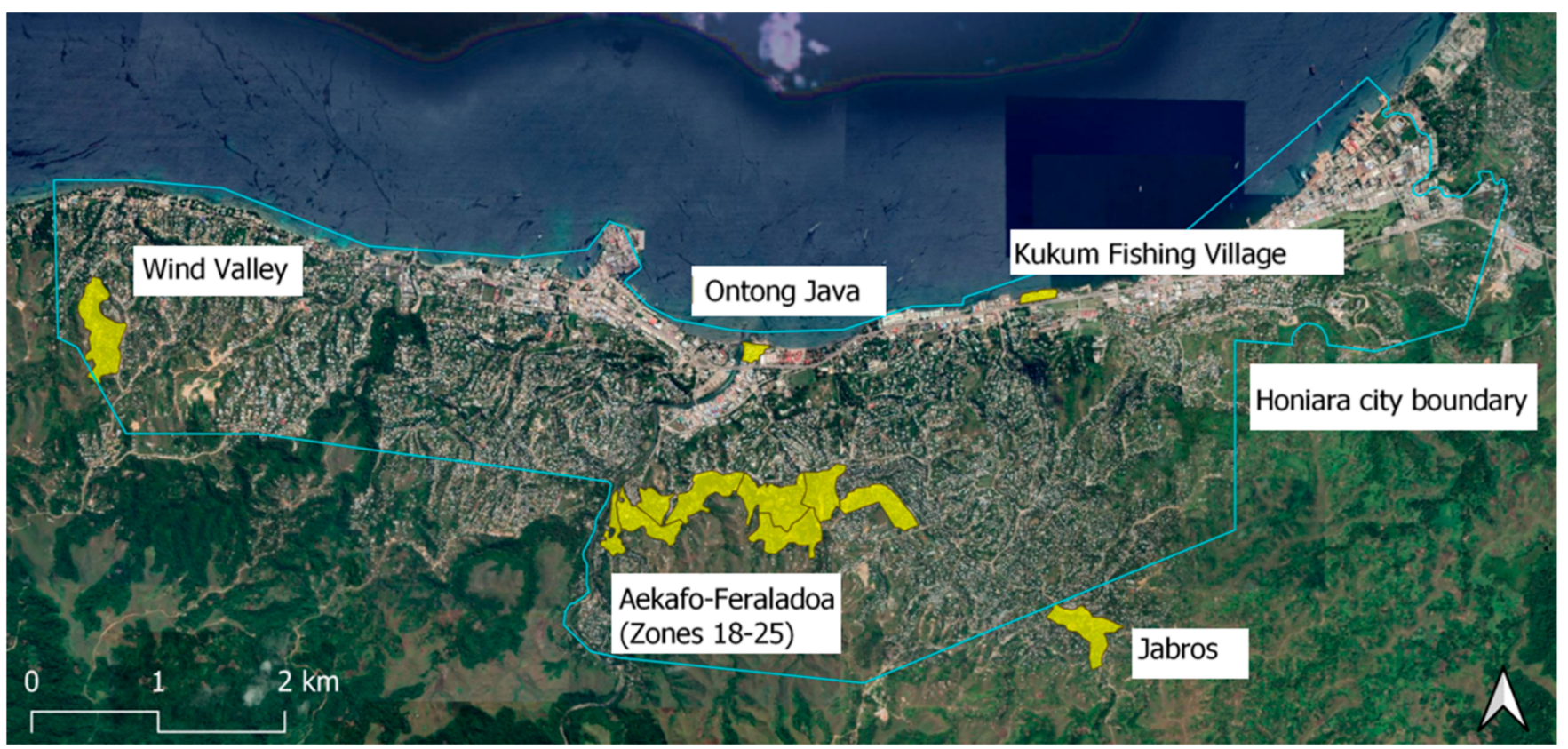

Figure 1. Honiara map of informal settlements (author-generated using data from Google Earth and Ministry of Lands, Housing and Survey).

Within the municipal boundary, formal land tenure is granted through 50-year period Fixed-Term Estate leases (FTEs) of government-held land, or 3-year Temporary Occupation Licenses (TOLs). TOLs were originally introduced in the 1970s to manage unplanned urban migration; however, most have lapsed. Government efforts to convert TOL areas to FTE through surveying, subdivision and valuation are underway but the conversion is not keeping up with the informal urban growth [5]. In addition, disputes remain, with some 
customary landowners challenging the location of the boundaries of the city established in 1978 [46].

Informal settlements cover about $15 \%$ of the city's total land area, housing approximately $35-40 \%$ of the population with population densities typically much higher than the rest of the city [16]. The Ontong Java settlement, one of the CRH project's vulnerability 'hotspots', has a density of 21,800 residents per square kilometer. Households in informal settlements also have inadequate access to water and sanitation infrastructures and limited access to other essential services [46].

More recently, the UNFCCC Adaptation Fund supported the CRH project to scope and implement actions identified by the HURCAP. CRH has four work packages at the community level: (i) producing comprehensive community profiles, (ii) developing climate action plans in hotspot settlements, (iii) designing engineering solutions based on community needs, and (iv) awareness raising and capacity development [5]. The community profiling provides important socioeconomic information to inform climate and land responses. The process was based on the vulnerability framework outlined in the HURCAP, and the household survey included 54 main questions about the three factors that influence vulnerability (exposure, sensitivity, and adaptive capacity) as well as six themes: household, livelihoods, housing conditions, utilities, land tenure, and climate change and disaster experiences.

An important element of both the HURCAP and CRH projects has been regular community workshops (see Figure 2) to better understand community needs, validate the vulnerability assessment and action plans, and understand the land tenure implications.

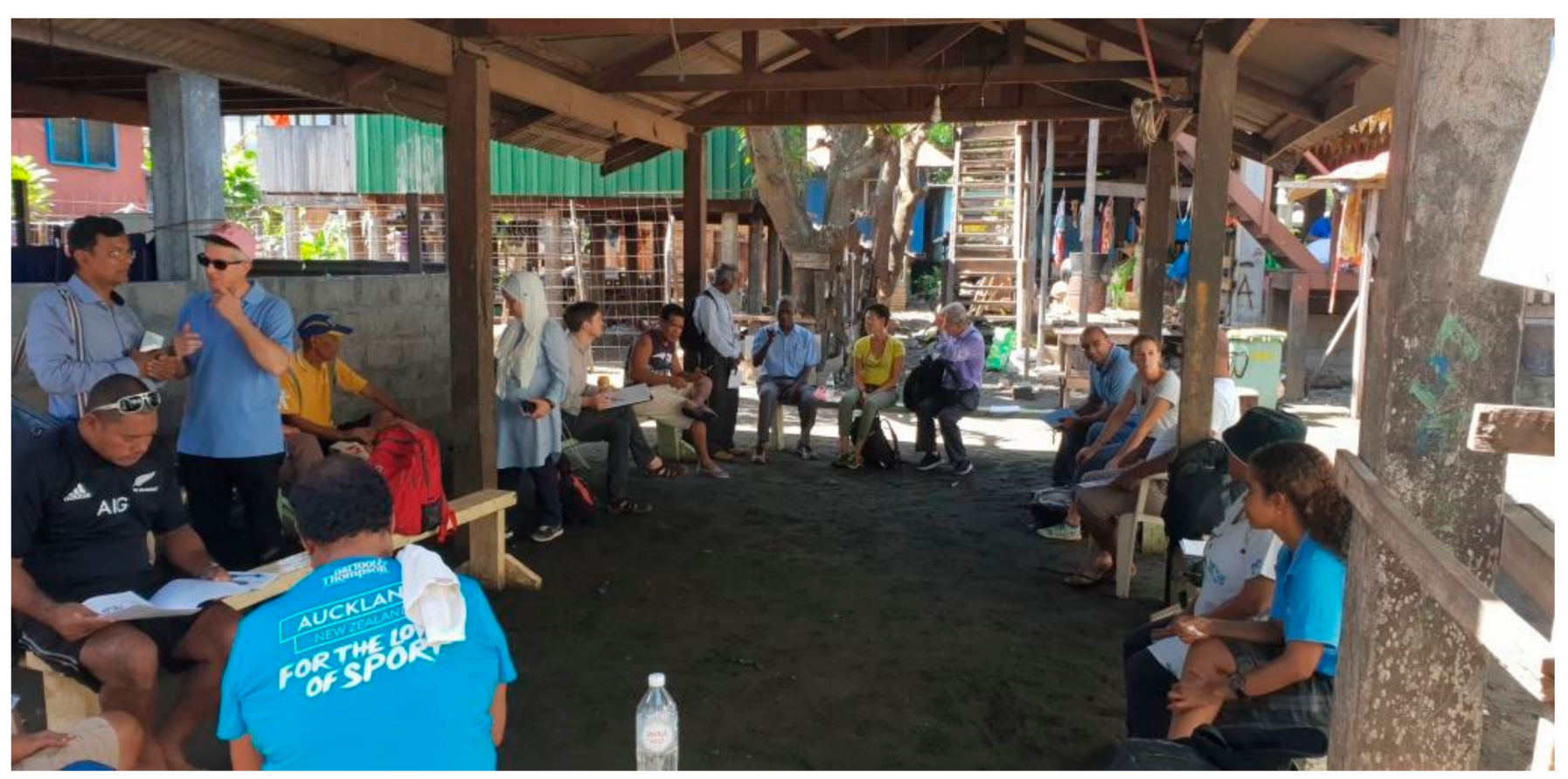

Figure 2. Community workshop in Ontong Java settlement (Photo credit: McEvoy).

In Honiara, the Ministry of Land Housing and Surveys' (MLHS) decision to take no action against informal settlers and those with lapsed TOL was an important first step in improving tenure security. This was evident in the recent COVID-19 survey with almost all (99 percent) respondents perceiving that they were safe from eviction, and 95 percent responding they had not been threatened with eviction due to COVID-19 in the 30 days prior to the survey [45].

The HURCAP and CRH projects build on ongoing initiatives, such as the Participatory Slum Upgrading Programme (PSUP), supported by UN-Habitat since 2008 and the Solomon Islands Government's efforts to 'formalize' housing through a more intensive process of 
subdivision and converting crown land to leased land, though with mixed success to date $[5,40]$. The process of land-use planning, PSUP and design of new subdivisions has benefited from the existing LiDAR data and high-resolution imagery from drones, creating a strong spatial framework. The drivers and climate vulnerabilities discussed above are summarized in Table 2 below, with the interlinkages with land issues further summarized in Table 3.

Table 2. Major issues and drivers impacting climate vulnerability.

\begin{tabular}{|c|c|}
\hline Issue/Driver & Climate Vulnerabilities \\
\hline $\begin{array}{l}\text { Urbanization leading to unplanned urban } \\
\text { growth in slums and informal settlements. } \\
\text { Increased density of development }\end{array}$ & More people exposed to climate impacts. \\
\hline $\begin{array}{l}\text { Slums and informal settlement with limited } \\
\text { access to formal water supply and sanitation }\end{array}$ & $\begin{array}{l}\text { Poor water supply and sanitation increases } \\
\text { climate vulnerability. }\end{array}$ \\
\hline $\begin{array}{l}\text { Informal settlement occupants may not be } \\
\text { included in DRR, CCA, resilience or disaster } \\
\text { reconstruction programs. }\end{array}$ & $\begin{array}{l}\text { May result in disaster affected households not } \\
\text { receiving disaster recovery and } \\
\text { reconstruction assistance. }\end{array}$ \\
\hline Poor quality house construction and materials & $\begin{array}{l}\text { Increased sensitivity to disasters and } \\
\text { climate impacts. }\end{array}$ \\
\hline Human mobility as an adaptive response & $\begin{array}{l}\text { Displacement due to disasters or } \\
\text { climate impacts. }\end{array}$ \\
\hline \multirow[t]{2}{*}{ Livelihood options and food security } & $\begin{array}{l}\text { Disasters lead to loss of some existing } \\
\text { livelihood options and impacting household } \\
\text { income and food security. }\end{array}$ \\
\hline & $\begin{array}{l}\text { DRR and CCA may lead to decision to resettle } \\
\text { households impacting livelihood options. }\end{array}$ \\
\hline
\end{tabular}

Table 3. Key interlinkages between land tenure and climate and pandemic stressors.

\begin{tabular}{|c|c|c|}
\hline Issue/Driver & Climate and Pandemic Vulnerabilities & $\begin{array}{c}\text { Land Issues in the Context of Climate } \\
\text { Change and Pandemics }\end{array}$ \\
\hline \multirow{2}{*}{$\begin{array}{l}\text { Urbanization leading to unplanned urban } \\
\text { growth in slums and informal settlements. } \\
\text { Increased density of development }\end{array}$} & $\begin{array}{c}\text { Climate-more people exposed to } \\
\text { climate impacts. }\end{array}$ & \multirow{2}{*}{$\begin{array}{l}\text { Ineffective urban planning and lack of } \\
\text { enforcement of building codes allows } \\
\text { unplanned high-density development. } \\
\text { Increased potential for land disputes }\end{array}$} \\
\hline & $\begin{array}{l}\text { Pandemic-increased vulnerability to } \\
\text { disease. Limited ventilation between } \\
\text { buildings exacerbates disease. }\end{array}$ & \\
\hline \multirow{2}{*}{$\begin{array}{l}\text { Slums and informal settlement with } \\
\text { limited access to formal water supply } \\
\text { and sanitation }\end{array}$} & $\begin{array}{c}\text { Climate-poor water supply and } \\
\text { sanitation increases climate vulnerability. }\end{array}$ & \multirow{2}{*}{$\begin{array}{l}\text { Impact on tenure security, potential } \\
\text { increased threat of eviction and } \\
\text { land disputes. }\end{array}$} \\
\hline & $\begin{array}{l}\text { Pandemic-poor water supply and } \\
\text { sanitation impacts health and spread } \\
\text { of disease. }\end{array}$ & \\
\hline \multirow{2}{*}{$\begin{array}{l}\text { Informal settlement occupants may not } \\
\text { be included in DRR, CCA, resilience or } \\
\text { disaster reconstruction programs }\end{array}$} & $\begin{array}{l}\text { Climate-may result in disaster affected } \\
\text { households not receiving disaster } \\
\text { recovery and reconstruction assistance. }\end{array}$ & \multirow{2}{*}{$\begin{array}{c}\text { Tenure insecurity can lead to exclusion } \\
\text { from government resilience and } \\
\text { other programs. }\end{array}$} \\
\hline & $\begin{array}{l}\text { Pandemic-may result in some } \\
\text { households not receiving government } \\
\text { pandemic grants and support. }\end{array}$ & \\
\hline \multirow{2}{*}{$\begin{array}{l}\text { Poor quality house construction } \\
\text { and materials }\end{array}$} & $\begin{array}{l}\text { Climate-increased sensitivity to } \\
\text { disasters and climate impacts. }\end{array}$ & \multirow{2}{*}{$\begin{array}{l}\text { Ineffective urban planning and } \\
\text { enforcement of building codes. }\end{array}$} \\
\hline & $\begin{array}{l}\text { Pandemic-densely populated } \\
\text { settlements impact pandemic responses } \\
\text { and spread of disease. }\end{array}$ & \\
\hline
\end{tabular}


Table 3. Cont.

\begin{tabular}{|c|c|c|}
\hline Issue/Driver & Climate and Pandemic Vulnerabilities & $\begin{array}{l}\text { Land Issues in the Context of Climate } \\
\text { Change and Pandemics }\end{array}$ \\
\hline \multirow{2}{*}{ Human mobility as an adaptive response } & $\begin{array}{l}\text { Climate- } \text { displacement due to disasters } \\
\text { or climate impacts. }\end{array}$ & \multirow{2}{*}{$\begin{array}{l}\text { Human mobility can lead to tenure } \\
\text { insecurity and landlessness }\end{array}$} \\
\hline & $\begin{array}{l}\text { Pandemic-pandemic restrictions limit } \\
\text { adaptive human mobility opportunities. }\end{array}$ & \\
\hline \multirow{3}{*}{ Livelihood options and food security } & $\begin{array}{l}\text { Climate-disasters lead to loss of some } \\
\text { existing livelihood options, impacting } \\
\text { household income and food security. }\end{array}$ & \multirow{3}{*}{$\begin{array}{l}\text { Reduced ability to pay rent or mortgage } \\
\text { payments may lead to eviction, } \\
\text { migration, or landlessness. Potential for } \\
\text { increased tenure insecurity. }\end{array}$} \\
\hline & $\begin{array}{l}\text { Climate-DRR and CCA may lead to } \\
\text { decisions to resettle households } \\
\text { impacting livelihood options. }\end{array}$ & \\
\hline & $\begin{array}{l}\text { Pandemic-existing livelihood options } \\
\text { restricted affecting household income } \\
\text { and household food security. }\end{array}$ & \\
\hline
\end{tabular}

\subsubsection{COVID-19 Issues in Honiara}

The 2020 UN-Habitat survey found that the average household income dropped due to the pandemic across all the surveyed settlements (see Figure 3). More than half the respondents were concerned about food running out at home, and $65 \%$ of those who received financial support used the money to buy food [45].

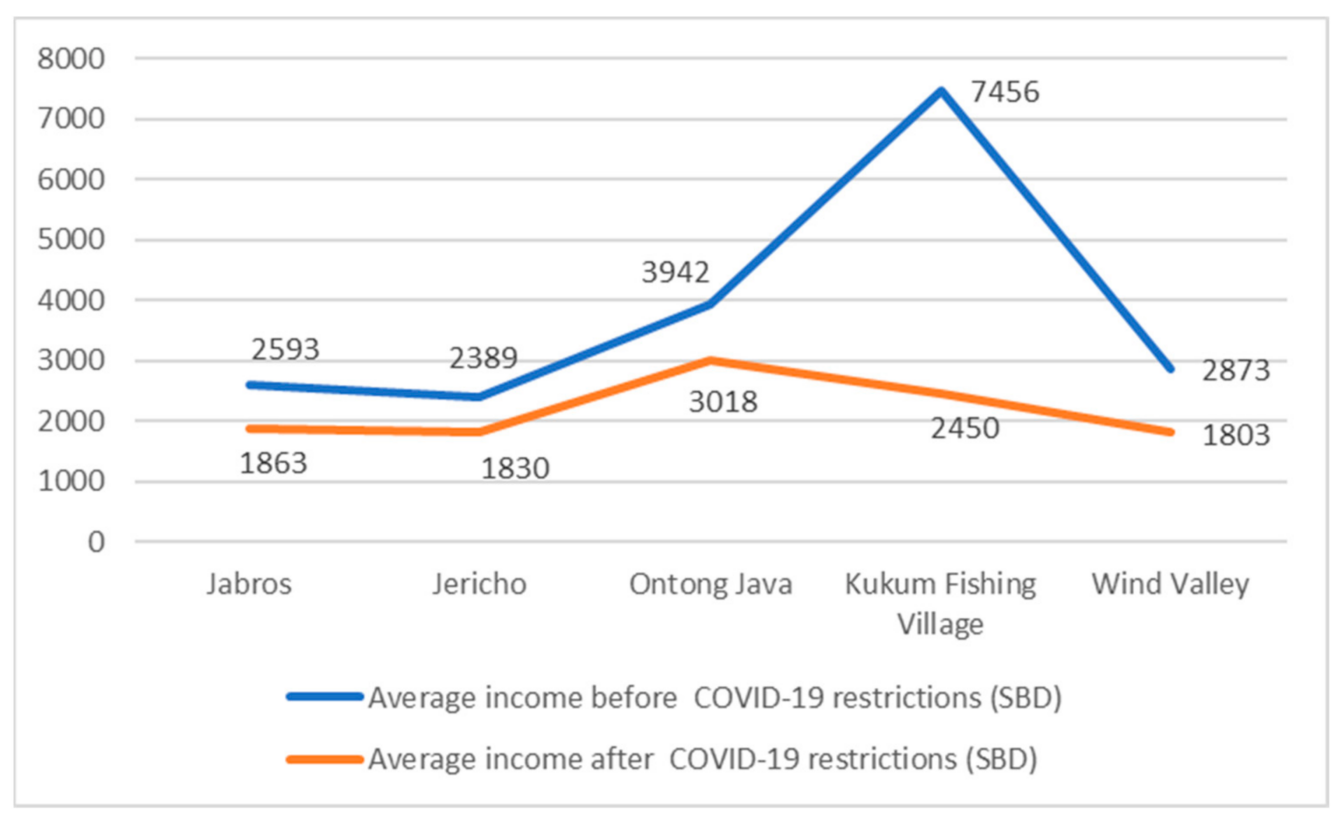

Figure 3. Average income before and after COVID-19 restrictions by settlement (Data from [16]).

One response has been to seek alternative livelihood options, such as farming and fishing for food (see Figure 4). The emphasis on self-sufficiency is reinforced by the findings from recent workshops in Honiara on gender and food security, which highlighted access to urban gardens as a 'survival' mechanism. However, this expansion of land use for fishing, agriculture or home gardens further increases the risk of land disputes (many bush gardens are outside the municipal boundary and on customary land). 


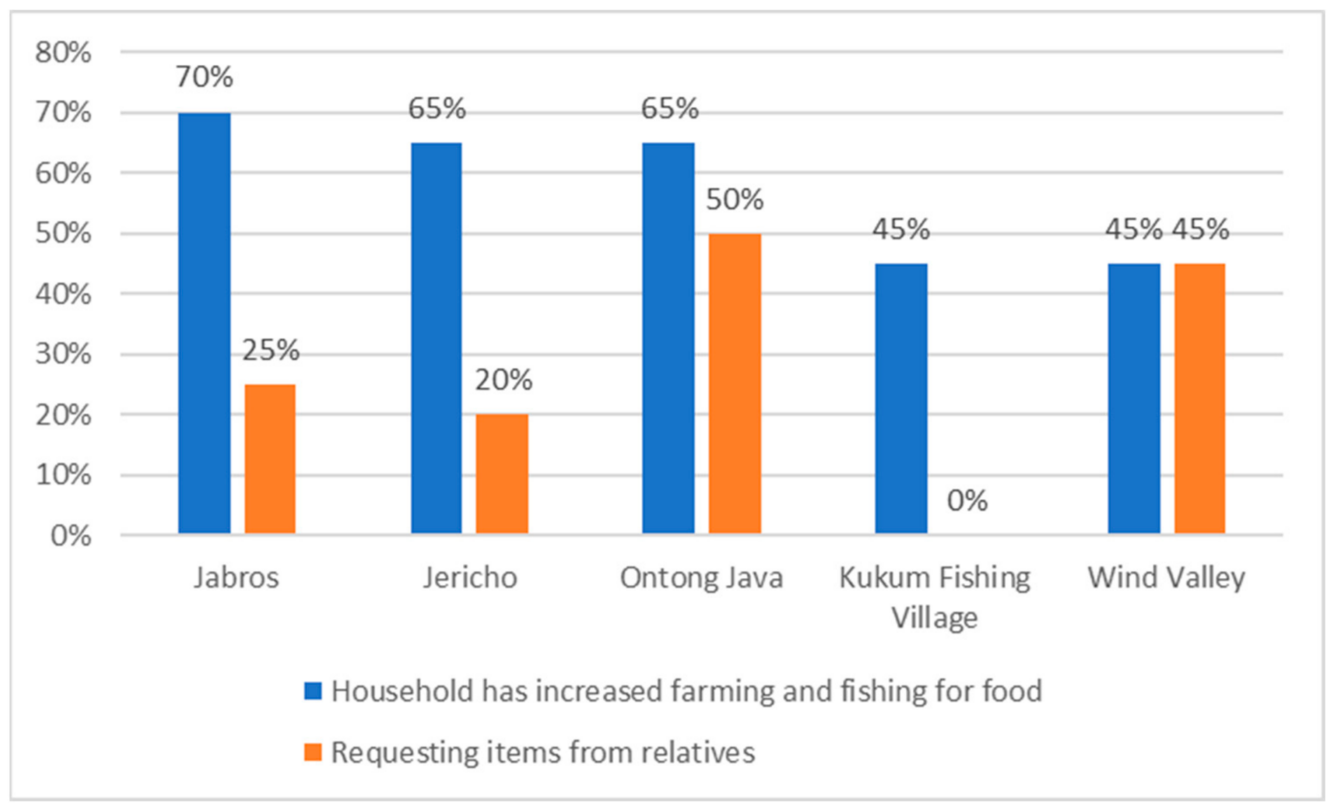

Figure 4. Traditional forms of social protection by settlement (Data from [16]).

The pandemic has highlighted many underlying socioeconomic problems, including impacts to household income and food security, exposing the fragility of informal settlements and slums. Households rely on limited livelihood options for daily subsistence and are frequently unable to afford soap, food, or medical treatment during movement restrictions or lockdowns [45]. The outbreak, and associated restrictions, have the potential to push many more into poverty and increase their climate vulnerability.

\subsection{Key Interlinkages between Urban Land Tenure and Climate and Pandemic Stressors}

As summarized in Tables 1 and 2 above, the urban drivers and interrelationships between underlying vulnerabilities to pandemics and climate change are complex. These include poverty, hazard-prone dwellings, lack of access to water and sanitation and basic services, overcrowded informal settlements, and limited open space. These vulnerabilities are compounded when a disaster event and a pandemic occur at the same time.

Urbanization and a lack of affordable and safe land means that informal settlements are often located in hotspots of natural hazards and in areas prone to flooding due to poor drainage. Houses built from poor-quality materials create new vulnerabilities to current and future climate impacts and pandemics. Densely populated housing, lack of formal connection to water and sanitation services, and poverty are underlying vulnerabilities for both COVID-19 and climate extremes and can contribute to the spread of infectious diseases. The urban poor and vulnerable groups within informal settlements can be more isolated from social networks and government services, and the informal settlement of land makes settlers more vulnerable to eviction. Larger household sizes create additional pressures during a pandemic lockdown, as houses also become the workplace for more family members, as well as a place for schoolwork and for health care. The result for households has been social, structural, economic, and political impacts with exaggerated vulnerabilities to multiple crises.

While voluntary human mobility can be an important adaptation response, pandemic lockdowns can make this unavailable, and climate impacts can lead to involuntary displacement or resettlement, potentially leading to tenure insecurity or landlessness.

Climate extremes and pandemics can lead to loss of livelihoods and impact on food security. Urbanization and climate drivers became more critical issues during the COVID19 pandemic. Loss of livelihoods affected the ability of households to pay mortgages or rent, sometimes forcing human mobility decisions that impacted tenure security and the quality 
of shelter. Reduced cash income during the pandemic reduced the purchasing capacities of the urban poor for basic food items, creating a decline in food security. Alternative livelihood strategies, including expanding agriculture or home gardens, increases the potential for land disputes. Indeed, land disputes and conflict can lead to increased landlessness as well as undermining climate adaptation efforts.

The key drivers and vulnerabilities discussed above and summarized in Tables 1 and 2 are combined in Table 3 below, followed by a discussion of each column.

The first column of Table 1 includes the major drivers impacting vulnerability to climate change and pandemics as well as tenure security as discussed in previous sections. These can be summarized as the following:

1. Urbanization manifests as unplanned urban growth in slums and informal settlements, often on hazard-prone land. An implication is the increased density of development, making more people exposed to natural disasters.

2. Slums and informal settlements often have limited access to formal water supply and sanitation.

3. Informal settlers may not be included in DRR, CCA, resilience or disaster reconstruction programs. This is at odds with the aim of leaving no one behind in resilience efforts.

4. Poor quality house construction and materials makes houses more sensitive to climate impacts.

5. Human mobility is often an important adaptive response. However, disasters can lead to involuntary displacement or resettlement, and pandemics can restrict human mobility.

6. Livelihood options and food security.

The second column summarizes the climate and pandemic vulnerabilities associated with each of these major drivers, as discussed in earlier sections. What is also evident from Table 3 is that there are many land issues common to climate and pandemic vulnerabilities. The remainder of this discussion will focus on addressing these common land issues and how FFP LAS can help address these in the context of climate change and pandemics.

\section{FFP LAS for Urban Resilience}

Urban resilience is a key objective in managing a combination of urbanization, climate, pandemic, and land issues. It promotes an integrated approach to addressing multiple shocks and stresses, such as climate extremes and pandemics, that impact urban systems both now and into the future [35]. Urban resilience is enhanced by explicitly considering insecure tenure and vulnerability to multiple stressors and, as informal settlements are a dominant form of new housing in cities of the Global South, any process to improve tenure security at scale must include all existing forms of land tenure as reflected in the 'continuum of land rights' concept (see Figure 5). This reinforces the fact that typically, a range of informal and formal tenure systems exist, varying in tenure security [47].

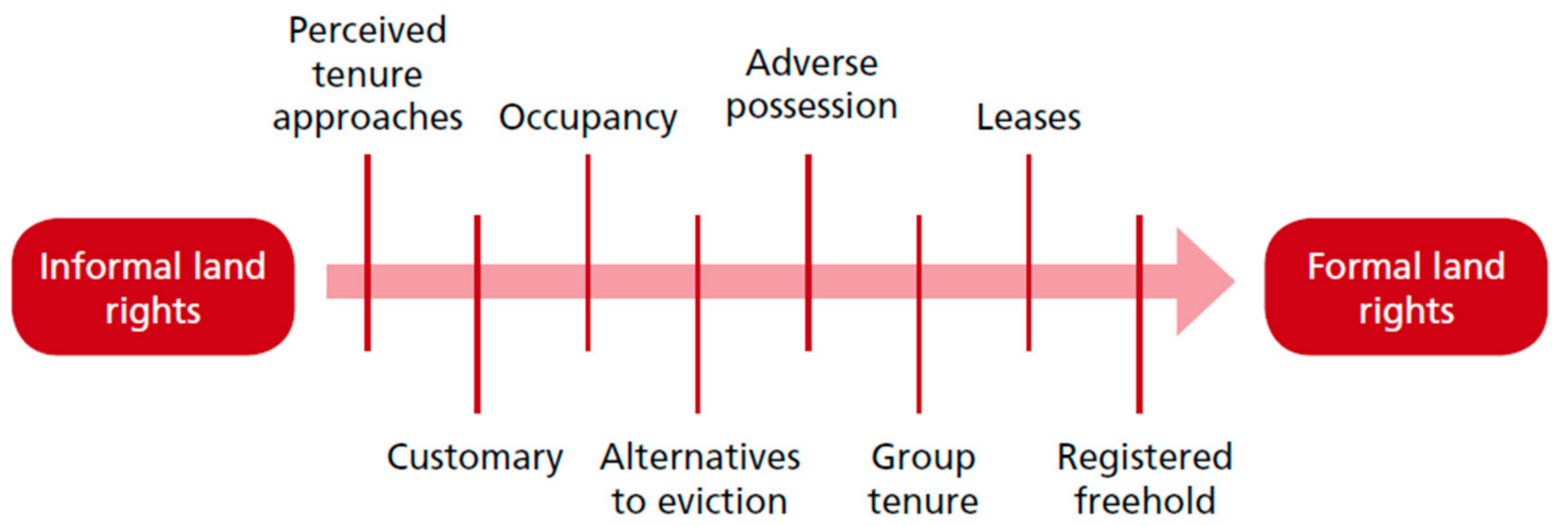

Figure 5. The continuum of land rights (Data from [47]). 
In line with the aim of the paper, this section describes how improving tenure security at scale using the FFP LAS approach can enhance climate resilience to both climate and pandemic impacts. The FFP LAS approach facilitates improving tenure security at scale, while recognizing a continuum of land rights, including all the existing people-to-land relationships. The FFP LAS approach to developing a spatial framework typically involves large-scale and high-resolution imagery that supports the adoption of visible (physical) boundaries [12].

Table 4 below builds on the land issues identified in previous tables and recommends appropriate land governance responses, and how FFP LAS can support improved land governance, based on project experience.

Table 4. Land governance and FFPLAS responses to land issues in the context of climate change and pandemics.

\begin{tabular}{|c|c|}
\hline $\begin{array}{l}\text { Land Issues in the Context of Climate } \\
\text { Change and Pandemics }\end{array}$ & $\begin{array}{c}\text { Land Governance Response, How FFP LAS } \\
\text { Can Help, and Related Land Tools }\end{array}$ \\
\hline $\begin{array}{l}\text { Ineffective urban planning and lack of } \\
\text { enforcement of building codes allows } \\
\text { unplanned high-density development. } \\
\text { Increased potential for land disputes }\end{array}$ & $\begin{array}{l}\text { Effective land-use planning and control; FFP } \\
\text { LAS: participatory enumeration, visible } \\
\text { boundaries defined on high resolution } \\
\text { imagery; tenure-responsive land-use planning. }\end{array}$ \\
\hline $\begin{array}{l}\text { Impact on tenure security, potential increased } \\
\text { threat of eviction and land disputes. }\end{array}$ & $\begin{array}{l}\text { Securing and safeguarding land tenure } \\
\text { rights, Effective land use planning and } \\
\text { control; FFP LAS: improving tenure security at } \\
\text { scale using methods that fit the } \\
\text { context-continuum of land rights, } \\
\text { participatory enumerations, visible boundaries } \\
\text { defined on high resolution imagery, } \\
\text { tenure-responsive land-use planning. }\end{array}$ \\
\hline $\begin{array}{l}\text { Tenure insecurity can lead to exclusion from } \\
\text { government resilience and other programs. }\end{array}$ & $\begin{array}{l}\text { Securing and safeguarding land tenure } \\
\text { rights, Effective land use planning and } \\
\text { control; FFP LAS: improving tenure security at } \\
\text { scale using methods that fit the context } \\
\text {-continuum of land rights, participatory } \\
\text { enumeration, visible boundaries defined on } \\
\text { high resolution imagery. }\end{array}$ \\
\hline $\begin{array}{l}\text { Ineffective urban planning and enforcement of } \\
\text { building codes. }\end{array}$ & $\begin{array}{l}\text { Effective land use planning and control; FFP } \\
\text { LAS: continuum of land rights, participatory } \\
\text { enumeration, visible boundaries defined on } \\
\text { high resolution imagery; tenure-responsive } \\
\text { land-use planning. }\end{array}$ \\
\hline $\begin{array}{l}\text { Human mobility can lead to tenure insecurity } \\
\text { and landlessness }\end{array}$ & $\begin{array}{l}\text { Securing and safeguarding land tenure } \\
\text { rights; FFP LAS: improving tenure security at } \\
\text { scale using methods that fit the } \\
\text { context-continuum of land rights, } \\
\text { participatory enumeration, visible boundaries } \\
\text { defined on high resolution imagery. }\end{array}$ \\
\hline $\begin{array}{l}\text { Reduced ability to pay rent or mortgage } \\
\text { payments may lead to eviction, migration, or } \\
\text { landlessness. Potential for increased tenure } \\
\text { insecurity. }\end{array}$ & $\begin{array}{l}\text { Securing and safeguarding land tenure } \\
\text { rights; FFP LAS: improving tenure security at } \\
\text { scale using methods that fit the } \\
\text { context-continuum of land rights, } \\
\text { participatory enumeration, visible boundaries } \\
\text { defined on high resolution imagery. }\end{array}$ \\
\hline
\end{tabular}

The first column lists the major land issues to be addressed related to each driver and vulnerability. These can be consolidated into the following major land issues to be addressed:

i. Ineffective urban planning and enforcement of building codes. 
ii. Tenure insecurity, loss of access to land, landlessness, potential increased threat of eviction and land disputes.

iii. A lack of formal land records can lead to exclusion from government resilience and other programs.

iv. Human mobility can lead to tenure insecurity or landlessness due to migration, involuntary resettlement, or displacement.

The following section discussed how these FFP LAS responses can support improved resilience. The right-hand column summarizes the appropriate land governance response, how FFP LAS can help address the land issues, and related land tools that support the FFP LAS approach. As discussed earlier, responsible land governance can be considered to comprise two major elements:

- Effective land-use planning and control: In Table 4, the common impacts due to poor land-use planning and control affecting both climate and pandemic vulnerability are informal settlement in hazard-prone areas, high housing density and poor housing quality. Lack of connection to formal water supply and sanitation are also common in informal settlements. Lack of formal records due to informal settlements can mean that households do not receive financial support during natural disasters and pandemics. FFP LAS can support effective land-use planning and control through recognizing, mapping, and recording all existing land tenure rights, using participatory enumeration, with visible boundaries defined on high resolution imagery. This information on land tenure systems informs a tenure-responsive approach to land-use planning.

- Securing and safeguarding land tenure rights: In Table 4, the common impacts due to poor tenure security affecting both climate and pandemic vulnerability include eviction, displacement, and involuntary resettlement, as well as loss of livelihood options. FFP LAS can support approaches to improve tenure security at scale, using methods that fit the context. This includes adopting the continuum of land rights to support the aim of tenure security for all, participatory enumeration to recognize and record existing land tenure rights, and mapping visible boundaries defined on high resolution imagery.

Building from project experience in Honiara, there are some clear lessons for the role of FFP LAS in resilience actions at the city level to improve tenure security at scale to support city-wide improvement to resilience to multiple stressors. This can be broadly considered to comprise three main stages:

1. Assessing the climate, pandemic, and land vulnerabilities and risk factors.

2. Resilience action planning.

3. Enhancing resilience through responsible land governance.

How FFP LAS potentially supports each of these stages is described in the following sections.

4.1. Assessing the Climate, Pandemic, and Land Vulnerabilities and Risk Factors to Support Recognizing and Recording Land Tenure Rights as well as Climate Action Planning

The UN-Habitat Cities and Climate Change Initiative (CCCI) has supported city-wide climate change Vulnerability and Risk Assessments (VRA), identifying 'hotspots', which often correspond with informal settlements. Adopting a system's response to risk and vulnerability, the VRA supports the development of Climate Action Plans to build the resilience of communities [45]. Based on internationally recognized methodologies, the VRA analyzes climate hazard characteristics, exposure, sensitivity, and adaptive capacities (see Figure 6). 


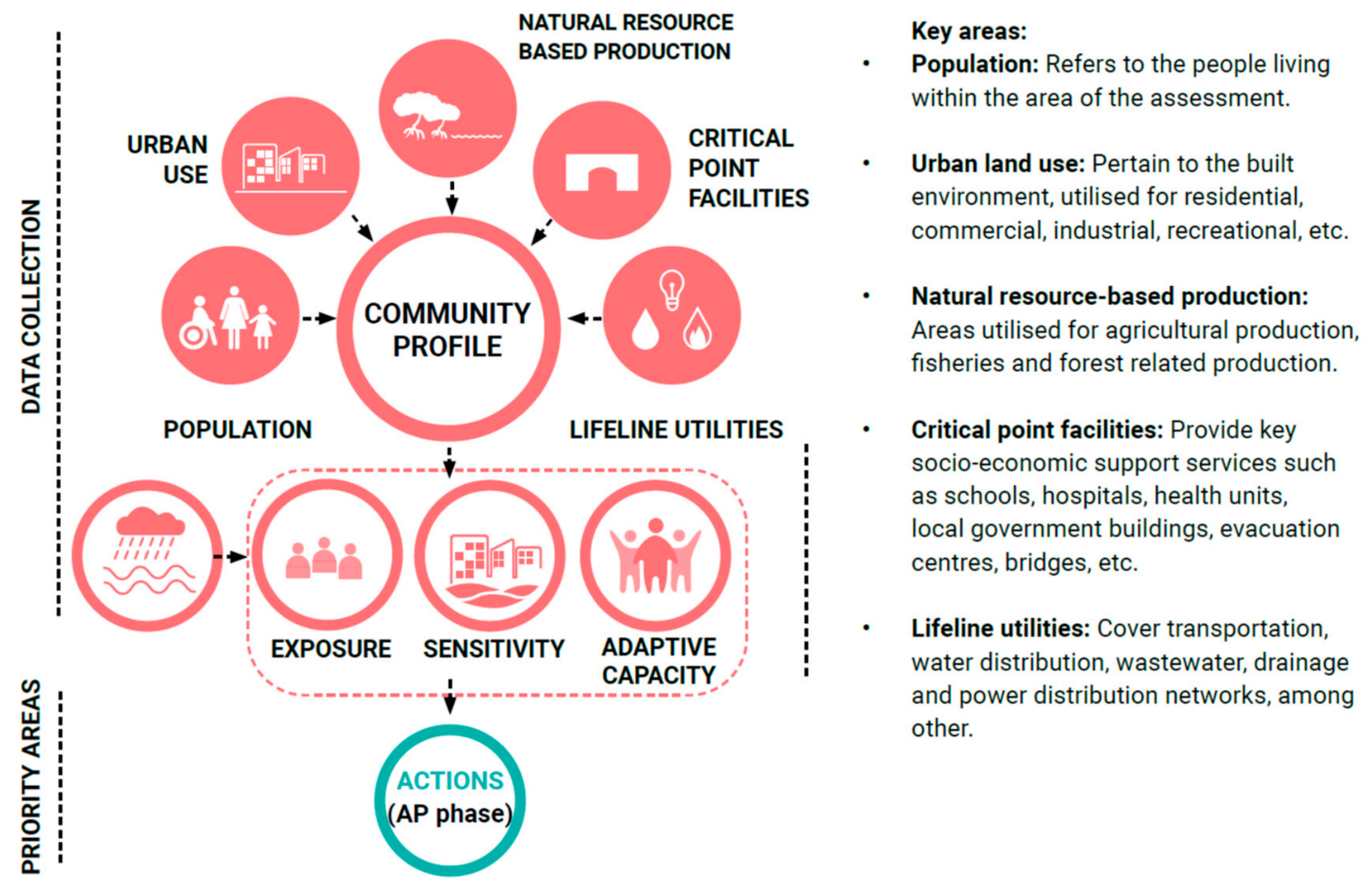

Figure 6. Vulnerability and risk assessment and action planning overview (Data from [45]).

The development of climate- and pandemic-resilient action plans require a deep understanding of the existing risk factors and vulnerabilities faced by households and other stakeholders. Resilience planning and implementation must apply to all existing households, not just those with formal land records. This household-level and settlementlevel understanding supports decisions on housing and tenure security, explicitly informed by climate impacts and a vulnerability assessment of affected urban informal settlements.

4.1.1. Community Profiling Supported by Participatory Enumeration to Recognize and Record Land Tenure and Vulnerability to Multiple Stressors

Community profiling based on a VRA also helps to design resilience action plans so that both climate and pandemic responses are integrated into a broader resilience and urban development process (UN-Habitat, 2020). Given the similarity of vulnerabilities caused by pandemics and climate impacts, this approach also fits a multi-stressor approach. These inform actions, including climate change adaptation, resilience building, urban planning, and infrastructure provision. A multi-stressor VRA supports a consultative, bottom-up, and more inclusive approach to the development of action plans. As the $\mathrm{CRH}$ project demonstrates, community profiling provides valuable understanding of the diversity of communities and their existing vulnerabilities. The profiling is based on participatory enumeration, using household surveys at the settlement level, supported by spatial information that provides mapping of the houses, public buildings, and other infrastructure in the settlement. Questions related to existing tenure arrangements and perceptions of tenure security allows assessment of the existing land tenure rights as the first stage in a FFP LAS approach to improving tenure security at scale.

\subsubsection{FFP LAS Approach to Building the Spatial Framework}

A key component of FFP LAS is the large-scale spatial framework comprising mapping that identifies the buildings and land parcels across the continuum of land rights to 
support decisions on securing land-tenure rights and land-use control [12]. In the Honiara case study, large-scale LiDAR imagery supported by small scale imagery from drones provided an important spatial framework to support land-use planning, slum upgrading and the design of new subdivisions. This spatial framework also supported the community profiling and VRA. A low-cost approach using high-resolution imagery and adopting the principle of visible boundaries allows expansion of the land administration system at scale, using this imagery to support registration processes [6]. Once the spatial framework is developed, the imagery data are also very useful for supporting community profiling and vulnerability assessment processes, assessing tenure security, as well as supporting community consultation discussions on action plans. Mapping of tenure security based on the concept of the continuum of land rights is possible in the community profiling process. It provides the necessary baseline data to inform tenure-responsive land-use planning, using FFP LAS approaches [5].

\subsection{Action Planning}

The findings from the VRA lay the foundation for the resilience action plans (AP). The aim of the AP is to support decision making on community-based interventions to strengthen resilience to climate change, as well as to support local development [45]. Community profiling and a FFP LAS approach to developing a spatial framework provide the basis for the design of action plans and community and stakeholder consultation to validate these. This detailed understanding and mapping is also very useful for supporting the resolution of disputes over land. This detailed baseline information allows harmonization between resilience action planning and actions to improve tenure security, such as slum upgrading programs or land readjustment projects. The mapping and community profiling can also support systematic and sporadic formal land recording. The resilience action planning stage is where land issues can be mainstreamed into climate and pandemic action plans and, conversely, hazard-risk information can be mainstreamed into land administration and land-use planning.

\subsection{Enhancing Resilience through Responsible Land Governance}

\subsubsection{Securing and Safeguarding Land Tenure Rights at Scale}

Safeguarding all land tenure rights involves understanding, recording, and recognizing the complex, long-established and accepted social tenure relationships. Slum upgrading is a typical approach to improve the security of tenure and upgrade infrastructure and facilities in settlements, as well as reduce hazard risk. UN-Habitat's Participatory Slum Upgrading Programme (PSUP) seeks to address vulnerability and marginalization during informal settlements upgrading [45].

Safeguarding all land tenure rights requires all existing people-to-land relationships to be recorded and recognized. A FFP LAS approach is necessary to do this complex task at scale, based on the participatory enumeration that informs community profiles as discussed above. FFP LAS supports the data collection and recording of informal land rights as well as formal land rights. Land tools for recording the people-to-land relationship, including social tenures, can be used to support the recognizing and recording of land tenure rights, especially for poor and informal settlers. One example is the Social Tenure Domain Model (STDM), which can record complex land-people relationships based on the Land Administration Domain Model and can later be upgraded for inclusion in the formal register of land records.

The FFP LAS approach was a piloted project in Nepal involving the post-earthquake data collection and recordation of customary and informal land rights, using STDM. The documented land information was certified and used to inform decisions on the allocation or reconstruction of grants, and support the land tools used to improve tenure security, as well as support the processes of relocation and reconstruction in four settlements in the Dolakha district in Nepal [7]. 


\subsubsection{Tenure-Responsive Land-Use Planning in the Context of Climate Change} and Pandemics

Community profiling, VRA and action plans help to mainstream climate and pandemic considerations in land-use planning. Effective land-use planning is necessary to restrict housing built in hazard-prone locations, and to support slum upgrading where informal settlement is well established. Improvement in community resilience to climate and pandemic stressors requires improving housing quality, connection to formal water supply and sanitation, and tenure insecurity in informal settlements. The community profiling based on VRA and an assessment of tenure security, supported by the FFP LAS spatial framework and recording of the people-land relationships is a strong basis for effective land-use planning and control. This means that land-use planning can be both tenureresponsive and cognizant of vulnerabilities and risks.

\section{Conclusions}

Based on an extensive literature review, and participatory action research based in Honiara, this paper discussed how improving tenure security at scale using the FFP LAS approach can enhance community resilience. Vulnerability to climate change and pandemics is a widespread challenge in slums and informal settlements. As tenure insecurity is an important factor in vulnerability, resilience efforts must address both vulnerability and tenure insecurity at scale. FFP LAS is necessary for improved tenure security at scale, with an approach that includes emphasizing adopting visible boundaries and the use of large-scale imagery to support the spatial, legal, and institutional components of land administration. Lessons from a current resilience project shows that the FFP LAS, informed by vulnerability assessments and community profiling, can support interventions aiming to scale up the number of households with security of tenure and improved resilience outcomes as informal settlements grow.

This paper describes how improving tenure security at scale using the FFP LAS approach can enhance climate resilience to both climate and pandemic impacts. This can be achieved at the city and settlement levels by including tenure in vulnerability and risk assessments (VRA) and the development of resilience action plans, as well as using VRA to inform efforts to improve tenure security, reduce land disputes and make land-use planning more effective.

We described how FFP LAS can support the two components of responsible land governance: (i) effective land-use planning and control, and (ii) securing and safeguarding land tenure rights. This includes developing a spatial framework based on imagery to support both VRA and action planning, as well as land-use planning, slum upgrading and subdivision design. Adopting the continuum of land rights, the other key aspect of the FFP LAS approach is using low-cost participatory enumeration methods and tools, such as the STDM to record all existing people-to-land relationships to allow all de facto and de jure tenures to be included in efforts to improve resilience and tenure security.

We contend that the FFP land administration approach, informed by participatory enumeration of the complexities of urban land tenure, can support scaling up efforts to improve tenure security and deliver more effective and equitable climate resilience actions for vulnerable urban communities in the Global South. Given the similarities in the vulnerabilities due to climate change and pandemics, the FFP LAS approach has broad applications in development efforts to reduce risk and improve resilience.

Author Contributions: Conceptualization, D.M. (David Mitchell) and D.M. (Darryn McEvoy); methodology, D.M. (David Mitchell), B.B., M.S.S., S.H. and D.M. (Darryn McEvoy); formal analysis, D.M. (David Mitchell), B.B., M.S.S., S.H. and D.M. (Darryn McEvoy); investigation, D.M. (David Mitchell), B.B., M.S.S., S.H. and D.M. (Darryn McEvoy).; writing—original draft preparation, D.M. (David Mitchell), B.B., M.S.S., S.H. and (Darryn McEvoy); writing-review and editing, D.M. (David Mitchell), B.B., M.S.S., S.H. and D.M. (Darryn McEvoy). All authors have read and agreed to the published version of the manuscript. 
Funding: The Climate Resilient Honiara is funded by the UNFCCC Adaptation Fund and administered by UN-Habitat. Funding of the publication costs for this article has kindly been provided by the School of Land Administration Studies, University of Twente, in combination with Kadaster International. the Netherlands.

Institutional Review Board Statement: Not applicable.

Informed Consent Statement: Not applicable.

Data Availability Statement: Not applicable.

Acknowledgments: Climate Resilient Honiara is funded by the UNFCCC Adaptation Fund and administered by UN-Habitat.

Conflicts of Interest: The authors declare no conflict of interest.

\section{References}

1. Yohe, G.W.; Lasco, Q.K.; Ahmad, N.W.; Arnell, S.J.; Cohen, C.; Janetos, A.C.; Perez, R.T. Perspectives on climate change and sustainability. In Climate Change 2007: Impacts, Adaptation and Vulnerability. Contribution of Working Group II to the Fourth Assessment Report of the Intergovernmental Panel on Climate; Parry, M.L., Canziani, O.F., Palutikof, J.P., van der Linden, P.J., Hanson, C.E., Eds.; Cambridge University Press: Cambridge, UK, 2007; pp. 811-841.

2. Dodman, D.; Brown, D.; Francis, K.; Hardoy, J.; Johnson, C.; Satterthwaite, D. Understanding the Nature and Scale of Urban Risk in Low- and Middle-income Countries and Its Implications for Humanitarian Preparedness, Planning and Response; Human Settlements Discussion Paper Series_Climate Change and Cities 4; International Institute for Environment and Development: London, UK, 2013.

3. Mitchell, D.; McEvoy, D. Land Tenure and Climate Vulnerability; UN-Habitat: Nairobi, Kenya, 2019.

4. Unger, E.-M.; Zevenbergen, J.; Bennett, R. On the need for pro-poor land administration in disaster risk management. Surv. Rev. 2016, 49, 437-448. [CrossRef]

5. McEvoy, D.; Mitchell, D.; Trundle, A. Land tenure and urban climate resilience in the South Pacific. Clim. Dev. 2020, 12, 1-11. [CrossRef]

6. Mitchell, D.; Enemark, S.; van der Molen, P. Climate resilient urban development: Why responsible land governance is important. Land Use Policy 2015, 48, 190-198. [CrossRef]

7. Unger, E.; Chhatkuli, R.R.; Antonio, D.; Lemmen, C.; Zevenbergen, J.; Bennett, R.; Dijkstra, P. Creating Resilience to Natural Disasters Through Fit-For-Purpose Land Administration in Nepal. In Proceedings of the 2019 World Bank Conference on Land and Poverty, Washington, DC, USA, 25-29 March 2019.

8. CFS; FAO. Voluntary Guidelines on the Responsible Governance of Tenure of Land, Fisheries and Forests in the Context of National Food Security; Committee on World Food Security ; UN FAO: Rome, Italy, 2012.

9. Farha, L. Housing, the Front-Line Defence against the COVID-19 Outbreak. Says UN Expert, OHCHR. 2021. Available online: https:/ / www.ohchr.org/EN/NewsEvents/Pages/DisplayNews.aspx?NewsID=25727 (accessed on 12 February 2021).

10. USAID. Impact of COVID-19 on Women's Customary Land Rights and Livelihoods in Southern Africa, ABA, ARICA. 2020. Available online: https://www.usaid.gov/sites/default/files/documents/ABA-ARISA_Impact_of_COVID_19_on_Womens_ Customary_Land_Rights_and_Livelihoods_Dec_2020.pdf (accessed on 22 April 2021).

11. Sait, M.S. Should Monrovian Communities Agree to Voluntary Slum Relocations: Land, Gender and Urban Governance. In Land Issues for Urban Governance in Sub-Saharan Africa; Home, R., Ed.; Springer: Cham, Switzerland, 2021; pp. 339-354.

12. Enemark, S.; McLaren, R.; Lemmen, C. Fit-for-Purpose Land Administration: Guiding Principles for Country Level Implementation; UN-Habitat; GLTN: Nairobi, Kenya, 2016.

13. Lengoiboni, M.; Richter, C.; Asperen, P.; Zevenbergen, J. Initial Insights on Land Adjudication in a Fit-for-Purpose Land Administration. Land 2021, 10, 414. [CrossRef]

14. Trundle, A.; McEvoy, D. Honiara Urban Resilience and Climate Action Plan; UN-Habitat: Fukuoka, Japan, 2017.

15. McEvoy, D.; Barth, B.; Trundle, A.; Mitchell, D. Reflecting on a journey from climate change vulnerability assessments to the implementation of climate resilience actions: Honiara, Solomon Islands. In Urban Resilience in the Asia Pacific: Challenges and Opportunities for Addressing Disasters and Climate Change in the Built Environment; Routledge: Oxford, UK, 2020.

16. UN-Habitat. Rapid Assessment of Covid-19 in Informal Settlements in Solomon Islands Insights into Socio-Economic Impacts on Residents in 5 Communities across Honiara, October 2020; UN-Habitat: Suva, Fiji, 2020.

17. Patz, J.A.; Daszak, P.; Tabor, G.M.; Aguirre, A.A.; Pearl, M.; Epstein, J.; Wolfe, N.D.; Kilpatrick, A.M.; Foufopoulos, J.; Molyneux, D.; et al. Unhealthy Landscapes: Policy Recommendations on Land Use Change and Infectious Disease Emergence. Environ. Health Perspect. 2004, 112, 1092-1098. [CrossRef]

18. Murray, K.A.; Daszak, P. Human ecology in pathogenic landscapes: Two hypotheses on how land use change drives viral emergence. Curr. Opin. Virol. 2013, 3, 79-83. [CrossRef]

19. Acuto, M. COVID-19: Lessons for an Urban(izing) World. One Earth 2020, 2, 317-319. [CrossRef] 
20. Moraci, F.; Errigo, M.F.; Fazia, C.; Campisi, T.; Castelli, F. Cities under pressure: Strategies and tools to face climate change and pandemic. Sustainability 2020, 12, 7743. [CrossRef]

21. Cooper, D.H.; Nagel, J. Lessons from the pandemic: Climate change and COVID-19. Int. J. Sociol. Soc. Policy 2021. [CrossRef]

22. El Hamichi, S.; Gold, A.; Murray, T.G.; Graversen, V.K. Pandemics, climate change, and the eye. Graefe's Arch. Clin. Exp. Ophthalmol. 2020, 258, 2597-2601. [CrossRef]

23. The Lancet Planetary Health. A Pandemic Era. Lancet Planet Health 2021, 5, e1. [CrossRef]

24. Di Marco, M.; Baker, M.L.; Daszak, P.; De Barro, P.; Eskew, E.A.; Godde, C.M.; Harwood, T.D.; Herrero, M.; Hoskins, A.J.; Johnson, E.; et al. Opinion: Sustainable development must account for pandemic risk. Proc. Natl. Acad. Sci. USA 2020, 117, $3888-3892$. [CrossRef] [PubMed]

25. Terraube, J.; Fernández-Llamazares, Á. Strengthening Protected Areas to Halt Biodiversity Loss and Mitigate Pandemic Risks. Curr. Opin. Environ. Sustain. 2020, 46, 35-38. [CrossRef] [PubMed]

26. Chin, A.; Cui, X.; Gillson, L.; Nelson, D.; Taylor, M.P.; Vanacker, V.; Wang, E. Anthropocene in an age of pandemics. Anthropocene 2020. [CrossRef]

27. Plowright, R.K.; Reaser, J.K.; Locke, H.; Woodley, S.J.; Patz, J.A.; Becker, D.J.; Oppler, G.; Hudson, P.J.; Tabor, G.M. Land use-induced spillover: A call to action to safeguard environmental, animal, and human health. Lancet Planet. Health 2021, 5, e237-e245. [CrossRef]

28. Nicola, M.; Alsafi, Z.; Sohrabi, C.; Kerwan, A.; Al-Jabir, A.; Iosifidis, C.; Agha, M.; Agha, R. The socio-economic implications of the coronavirus and COVID-19 pandemic: A review. Int. J. Surg. 2020, 78, 185-193. [CrossRef]

29. Huchzermeyer, M.; Karam, A. The continuing challenge of informal settlements: An introduction. In Informal Settlements: A Perpetual Challenge; Huchzermeyer, M., Karam, A., Eds.; Juta and Company Ltd.: Johannesburg, South Africa, 2006; Volume 1, pp. 1-16.

30. Penrose, K.; De Castro, M.C.; Werema, J.; Ryan, E.T. Informal Urban Settlements and Cholera Risk in Dar es Salaam, Tanzania. PLoS Negl. Trop. Dis. 2010, 4, e631. [CrossRef]

31. UN Habitat. Cities and Pandemics: Towards a More Just, Green and Healthy Future; UN Habitat: Nairobi, Kenya, 2021.

32. Wilkinson, A.; Ali, H.; Bedford, J.; Boonyabancha, S.; Connolly, C.; Conteh, A.; Dean, L.; Decorte, F.; Dercon, B.; Dias, S.; et al. Local response in health emergencies: Key considerations for addressing the COVID-19 pandemic in informal urban settlements. Environ. Urban. 2020, 32, 503-522. [CrossRef]

33. Chigbu, U.E.; Onyebueke, V.U. The COVID-19 pandemic in informal settlements: (re)considering urban planning interventions. Town Plan. Rev. 2021, 92, 115-121. [CrossRef]

34. Corburn, J.; Vlahov, D.; Mberu, B.; Riley, L.; Caiaffa, W.T.; Rashid, S.F.; Ko, A.; Patel, S.; Jukur, S.; Martínez-Herrera, E.; et al. Slum Health: Arresting COVID-19 and Improving Well-Being in Urban Informal Settlements. J. Hered. 2020, 97, 348-357. [CrossRef]

35. Kiddle, G.L.; McEvoy, D.; Mitchell, D.; Jones, P.; Mecartney, S. Unpacking the Pacific Urban Agenda: Resilience Challenges and Opportunities. Sustainability 2017, 9, 1878. [CrossRef]

36. National Statistics Office. Provisional Count: 2019 National Population and Housing Census. Ministry of Finance and Treasury, Government of Solomon Islands. 2020. Available online: https://www.solomonchamber.com.sb/media/1997/provisional_ count-2019_census_result.pdf (accessed on 12 March 2021).

37. Firth, S. Instability in the Pacific Islands: A Status Report. Lowy Institute. 2018. Available online: https://www.lowyinstitute. org/publications/instability-pacific-islands-status-report (accessed on 12 March 2021).

38. Oliver-Smith, A.; and de Sherbinin, A. Resettlement in the Twenty-First Century, Crisis, Forced Migration Review 45.2014. Available online: https:/ / www.fmreview.org/crisis/oliversmith-desherbinin (accessed on 16 March 2021).

39. Jones, P. Pacific Urbanisation and the Rise of Informal Settlements: Trends and Implications from Port Moresby. Urban Policy Res. 2012, 30, 145-160. [CrossRef]

40. ADB. Pacific Economic Monitor: July 2014-Midyear Review (Cook Islands, Fiji, Kiribati, Marshall Islands, Micronesia, Federated States of, Nauru, Palau, Papua New Guinea, Samoa, Solomon Islands, Timor-Leste, Tonga, Tuvalu, Vanuatu; Issue July 2014). Asian Development Bank. 2014. Available online: https://www.adb.org/publications/pacific-economic-monitor-july-2014 (accessed on 14 February 2021).

41. Wilson, C. Demanding the Future: Navigating the Pacific's Youth Bulge. Lowy Institute. 2020. Available online: https: // www.lowyinstitute.org/publications/demanding-future-navigating-pacific-youth-bulge (accessed on 22 March 2021).

42. Andrew, N.L.; Bright, P.; De La Rua, L.; Teoh, S.J.; Vickers, M. Coastal Proximity of Populations in 22 Pacific Island Countries and Territories. PLoS ONE 2019, 14, e0223249. [CrossRef]

43. SPREP; APAN. Report on Adaptation Challenges in Pacific Island Countries. SPREP. 2013. Available online: https://www.sprep. org/attachments / Publications / Adaptation_challenge_PICs_13_hr.pdf (accessed on 22 March 2021).

44. PACCSAP. Climate Variability, Extremes and Change in the Western Tropical Pacific: New Science and Updated Country Reports 2014, Solomon Islands. 2014. Available online: https:/ / www.pacificclimatechangescience.org/publications/reports/climatevariability-extremesand-change-in-the-western-tropical-pacific-2014/ (accessed on 24 March 2021). 
45. UN-Habitat. Climate Change Vulnerability and Risk-A Guide for Community Assessments, Action Planning and Implementation, Rise Up: Resilient Settlements for the Poor; UN-Habitat: Nairobi, Kenya, 2020.

46. Foukona, J.D. Urban Land in Honiara: Strategies and Rights to the City. J. Pac. Hist. 2015, 50, 504-518. [CrossRef]

47. UN-Habitat; IIRR; GLTN. Handling Land: Innovative Tools for Land Governance and Secure Tenure; UN-Habitat: Nairobi, Kenya, 2012; Available online: https:/ / gltn.net/download/handling-land-innovative-tools-for-land-governance-and-secure-tenure-eng2012/ (accessed on 11 February 2021). 